\title{
Analysis of causes of disease in Sundarbans natural mangrove
}

\author{
Awal, Mohd. Abdul \\ Environmental Scientist, (Ministry of Environment \& Forest), Founder \& Chief Advisor, (Health \& Pollutions Research Farm), and \\ Address: Long Island City, New York, USA \\ Email address: \\ abdul_awal2004@yahoo.com

\section{To cite this article:} \\ Awal, Mohd. Abdul. Analysis of Causes of Disease in Sundarbans Natural Mangrove. American Journal of Bioscience and \\ Bioengineering. Vol. 2, No. 2, 2014, pp. 18-32. doi: 10.11648/j.bio.20140202.11
}

\begin{abstract}
A serious disease (top dying) of H. fomes in Sundarbans is affecting millions of the trees. An inventory by Chaffey et al., (1985) revealed that there were about 45.2 million top dying trees in the Sundarbans of which 20 million had more than $50 \%$ of their crown affected by top dying. The loss of $H$. fomes will have a major impact on the Sundarbans mangrove ecosystem, as well as lead to economic losses. Despite various hypotheses as to the causes of this top-dying, the underlying causes are still not well understood. The present work has explored some of the possible factors involved, focussing particularly on the relationship between the amount of top-dying in different places and the concentrations of a number of chemical elements present in the soil and water, in order to test the hypothesis that chemical pollution might be responsible. Other factors such as the $\mathrm{pH}$, salinity and nutrient status were also assessed. Nine plots were selected for sampling of soil, water, and vegetation in order to categorise different areas in terms of their intensity of top-dying. 63 soil samples and 9 water samples were tested, mainly by ICPMS, to investigate certain parameters of the soil and water, such as $\mathrm{Sn}$, Exchangeable K, Soil $\mathrm{pH}, \mathrm{Pb}, \mathrm{Zn}, \mathrm{Ni}$, soil $\mathrm{pH}, \mathrm{CEC}$, soil nutrients, soil moisture content, and elemental concentrations of 32 other elements. Most of the elements studied had no significant correlation with the top dying of Heritiera fomes. However, Sn, Exchangeable $\mathrm{K}$, and soil $\mathrm{pH}$ were significantly related, and three elements, namely $\mathrm{Pb}, \mathrm{Zn}, \mathrm{Sr}$, were also close to significance. Of the hypotheses previously put forward to explain top-dying, the present results do not support enhanced salinity as the cause. It is likely that several of the above-mentioned environmental factors interact with each other to induce top dying in Sundri. But, the present results have showed that $\mathrm{Sn}$, Exchangeable $\mathrm{K}, \mathrm{Pb}, \mathrm{Sr}$ and $\mathrm{Zn}$ could be directly linked with top-dying of Heritiera fomes (Sundri) in Sundarbans ( Awal, 2007; 2009; 2014), particularly by weakening the vigour of the trees and allowing other factors such as pathological agents to attack the plants.
\end{abstract}

Keywords: Heritiera Fomes, Mangrove, Sundarbans, Disease of Plants, Natural Forest Resources, Sundarbans, Top-Dying, Causal Factors, Heavy Metal Concentrations

\section{Introduction}

Coastal and wetlands everywhere are under threat from agricultural intensification, pollution (Awal, 2007. 2009, 2014), major engineering schemes and urban development, (UN-ESCAP 1987; 1988). Coastal lands cover $6 \%$ of the world's land surface (Tiner, 1984). Mangroves in Asia including Bangladesh, India, and East Africa previously contained a much fuller range of species (Seidensticker, and Hai, 1983; Khan, 1997). Sundarbans natural mangrove forest resources usually create thick, organically rich sediments as their substrata. Most of the substrata in the tropics except under deltaic environments consist of mangrove peat which mainly derives from mangrove roots (Fujimoto et al., 1996; and Siddiqi et al., 1993).

Sundarban mangrove forests have great belowground productivity and play a significant role in carbon concentration not only above ground but also below ground. Mangrove ecosystems therefore provide a unique and valuable range of resources and services. Thus a great number of birds, mammals, fishes and invertebrates utilize mangroves like Sundarbans during at least one part of their life cycle (Siddiqi et al., 1993). Sundarban also provides a critical habitat for a diverse marine and terrestrial flora and 
fauna, and acts as a natural wind break, protecting low lands of the Khulna division and other parts of the country along with 3.5 million surrounding people, with their resources, from hurricanes, tidal surges and natural catastrophes. Also, several hundred thousand people of Bangladesh and India depend directly for their livelihood upon the Sundarbans (Field, 1995). Sundarbans is the breeding ground for juvenile fish, crabs, shrimps, and mollusks, and is also a prime nesting site for hundreds of birds, animals, reptiles, insects, and species of micro organism. In a healthy coastal ecosystem the forest detritus, consisting of leaves and branches from the mangroves, provides nutrients for the marine environment, and is the basis of intricate food webs and food chains associated directly through detritus to the planktonic and epiphytic algal food chains. Sundarban attracts and shelters fishes under the shade of mangrove, protects all water resources and terrestrial resources from tidal storms, cyclones, strong waves and winds, and also provides food as leaf-litter to fishes.

Many of the countries in Asia and In the U.S.A, and Australia also, mangroves are being adversely affected by both nearby developments and pollution problems (Peters et al., 1985). Coastal biological resources have been depleted by commercial fishing, including poison and blast fishing (Jones, 1992). In addition, pollution from shipping, in particular oil, and in some areas the discharge of toxic wastes, had adversely affected the marine environment (UNESCAP 1988). According the present result, the combined pollution of soil, in Sundarbans as a long term consequences, top-dying disease of Heritiera fomes might have created in Sundarbans.

\subsection{Location}

This natural forest resources (Sundarban mangrove forest) is located mainly at the southern portion of the Gangetic delta bordering on the Bay of Bengal of Bangladesh (Blasco, 1977; Naskar 1999; and Bakshi,1954; Thom, 1982, Figure 1.0). It occupies a flat deltaic swamp rarely exceeding 0.9 to $2.1 \mathrm{~m}$ above the sea level and most of the area is under water during the high spring tides of the monsoon and the major portion of land is a low plain with maximum $10 \mathrm{~m}$ height above mean sea level (FAO, 1994).

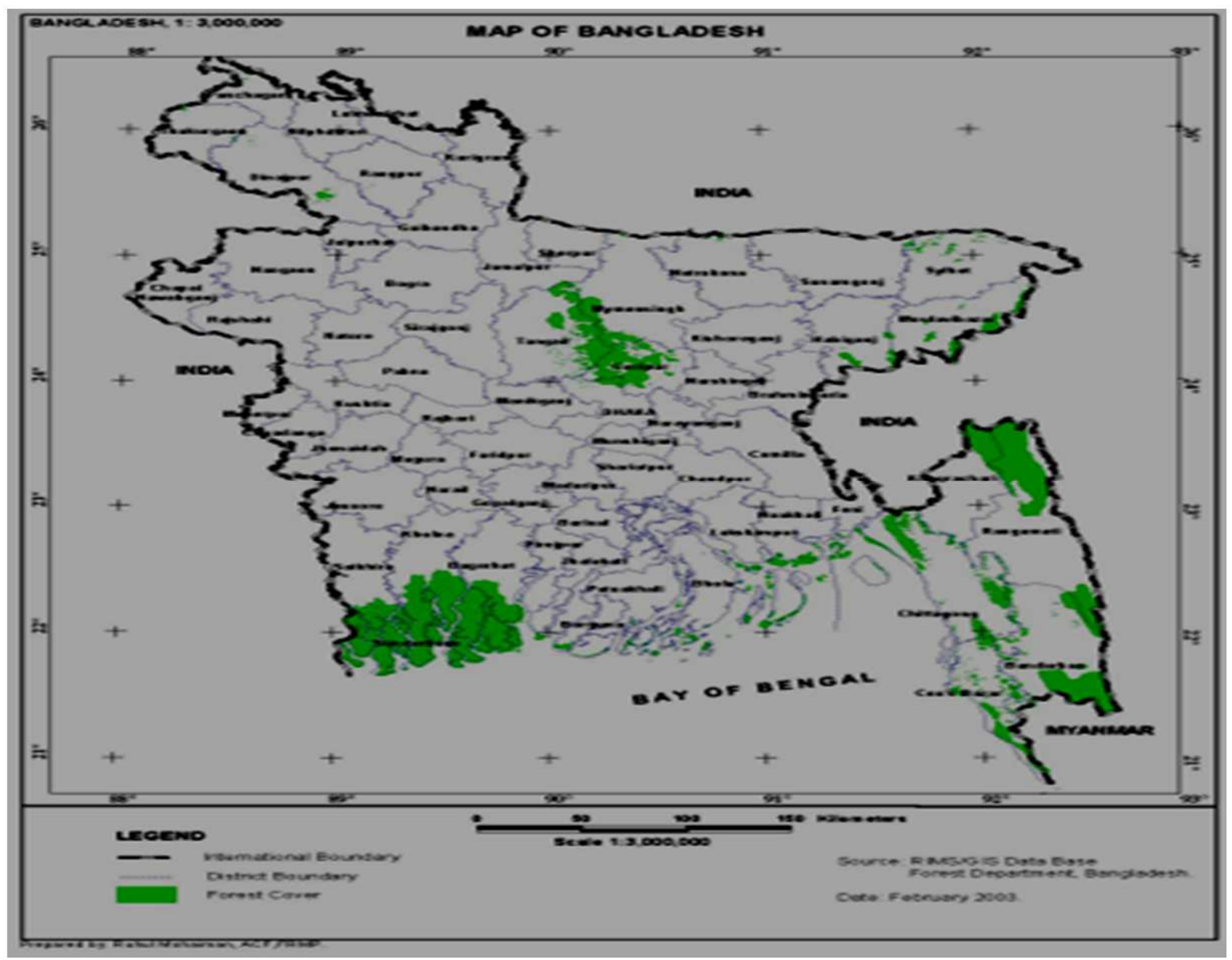

Figure 1. Map showing the administrative districts of Bangladesh, including the location of the Sundarbans (the shaded area in the south-west of the country).

Sundarbans is subdivided into 8 blocks (Rahman, 2003) and further subdivided into 55 compartments (Figure 2.0), varying in size from 4000-16,000 ha (Tamang, 1993), depending on the height classes \& stocking conditions of the forest trees. 


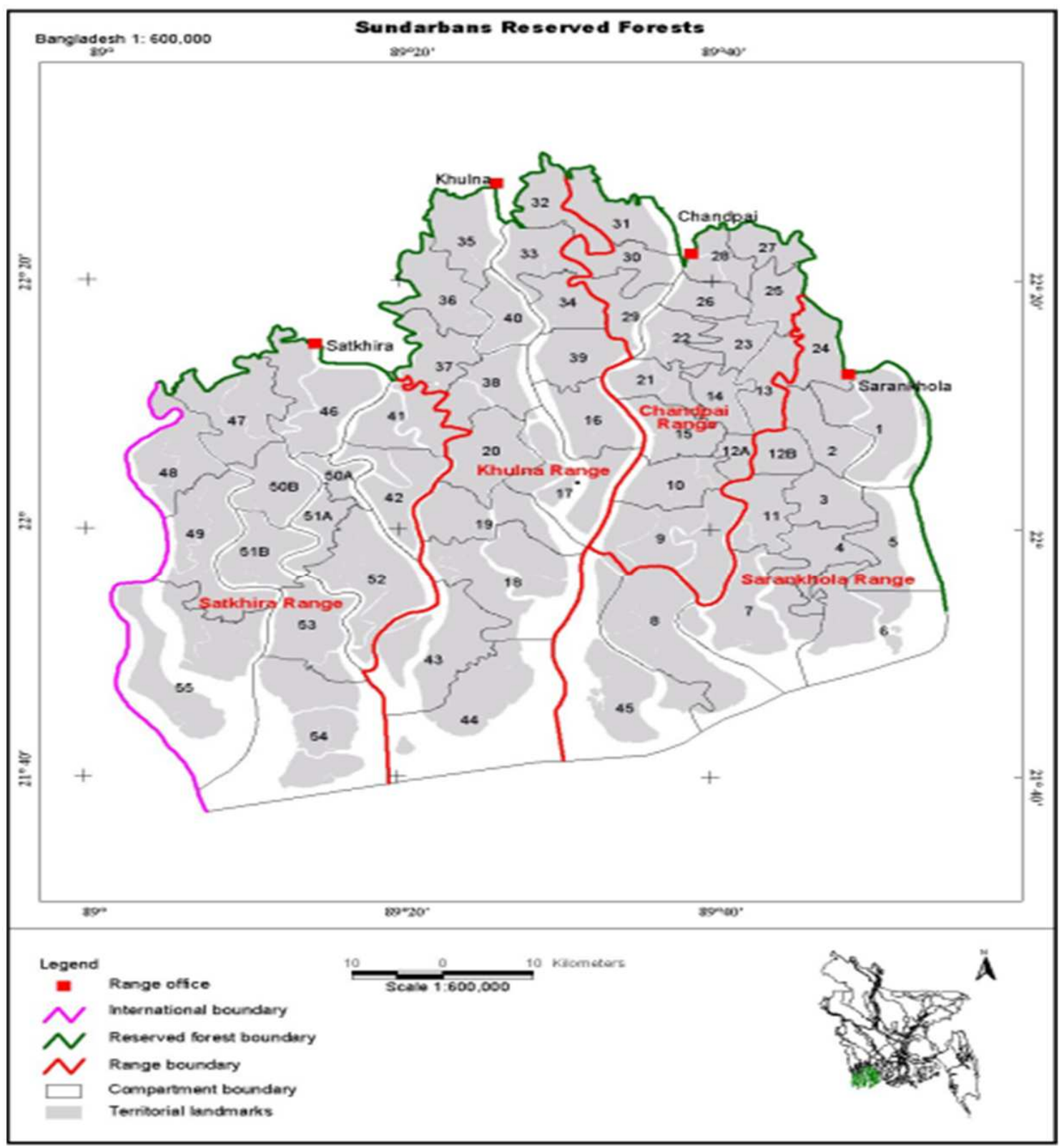

Figure 2. Shows compartment numbers and Ranges of Sundarbans Reserved Forests.

The forest lies just south of the topic between $21^{\circ} 38^{\prime}$ $22^{\circ} 30^{\prime}$ North latitudes and $89^{\circ} 0^{\prime}-90^{\circ} 0^{\prime}$ East longitudes. Within the total areas of the Sundarbans, Heritiera fomes constituted $63.8 \%$ among the total tree vegetation (Chaffey et al., 1985).

\subsection{Disease and Vegetation Changes}

Sundri is seriously affected by this unknown and most serious killer disease(Top-dying disease or dieback) leads to the death of Sundri (Heritiera fomes) trees and consequently to the decline of Sundri in the Sundarbans. This condition starts with a decline or death of foliage and twigs in the upper part of the tree, and gradually the symptoms extend downward. This gives a stag-headed condition to the affected trees (Gibson, 1975). This has led to increasing concern of the management of the forest. Sporadic or patchy occurrence of top dying of Sundri was mentioned early on by Troup (1921). Sundri top-dying was also reported by Curtis (1933) in the Sundarbans working plan, and this plan drew attention to the occurrence and severity of the problem (Chowdhury, 1983). The top dying of Sundri has been of particular concern since the 1970s and it has aggravated in recent years (Chowdhury, 1984; Gibson, 1975). Quantitative data regarding the extent of top dying was presented by Chaffey et al. (1985). The decline of Sundri at present due to top dying is in the range of $13-25 \%$, but $13-17 \%$ unsound (top dying) trees was reported in the Sundarbans in the 1920s (Ahmed, 1957). It is, therefore, suggested that the level of top dying (13-17\%) of Sundri over $5 \mathrm{~cm}$ d.b.h. during 1926-28 was only 
slightly lower than the $13-25 \%$ found during the enumeration of 1983-84. Top dying and the accumulation of dead Sundri trees reached such a proportion that it was clearly visible even to casual visitors (Sattar, 1977; Chowdhury, 1984).

In April 1973, a seven member team from different Departments of the Government inspected eleven compartments of Sundarbans to study the problem of top dying of Sundri, and prepared a report in May of that year. The principal observations of the team were the following: Top dying was scattered and limited to individual trees or small groups of trees; (ii) The incidence of top-dying was more in the northern compartments and reduced considerably in the southern ones; (iii) Top dying was more on the banks of rivers than inside the islands; (vi) The old large-size trees showed dead tops while the younger trees had good and healthy crowns. Loranthus (a fungal) attack was very common to the trees with dead tops; this was noticed towards the bottom of the dead trees. Canker was found to be very common irrespective of whether the trees were dead, dying or apparently healthy (Chowdhury, 1984). In the north central part of the Sundarbans, influenced by the Sibsa and Passur rivers, top dying of Sundri was severe in 1984. In that area seedling mortality is also very high. Representatives of young age classes are largely absent. The tree species Kakra, Passur, Bean and Keora also have shown signs of mortality in addition to Sundri in the same area (Chowdhury, 1984). These problems are still evident today.

\section{Methodology}

In this research work the various field and laboratory methods used in this study will be discussed.

\subsection{Field Sampling Methods}

The Sundarbans Reserved Forest is located at the south west corner of the Ganges River Delta close to the Bay of Bengal, mainly on the sea-shore line, river banks, channels, and small creeks. The location of the Sundarbans within Bangladesh has been shown in Figure 1.1.

\subsection{Site Selection and Location of the Study Area}

General reconnaissance of possible sites was made by visiting all the possible regional areas before categorizing and selecting plots for sampling.

It was decided to sample from the Chandpai area which is the mostly human accessible and ecologically polluted area. Three compartments from this regional area (range), namely numbers 26, 28 and 31, were selected because they were believed to represent a range of severity of top dying disease, based on relevant maps, documents, literature, consultations with forest professionals, and surrounding peoples. The location of these compartments within the Chandpai area, and the location of this area in the wider Sundarbans is shown in Figure 2.1.

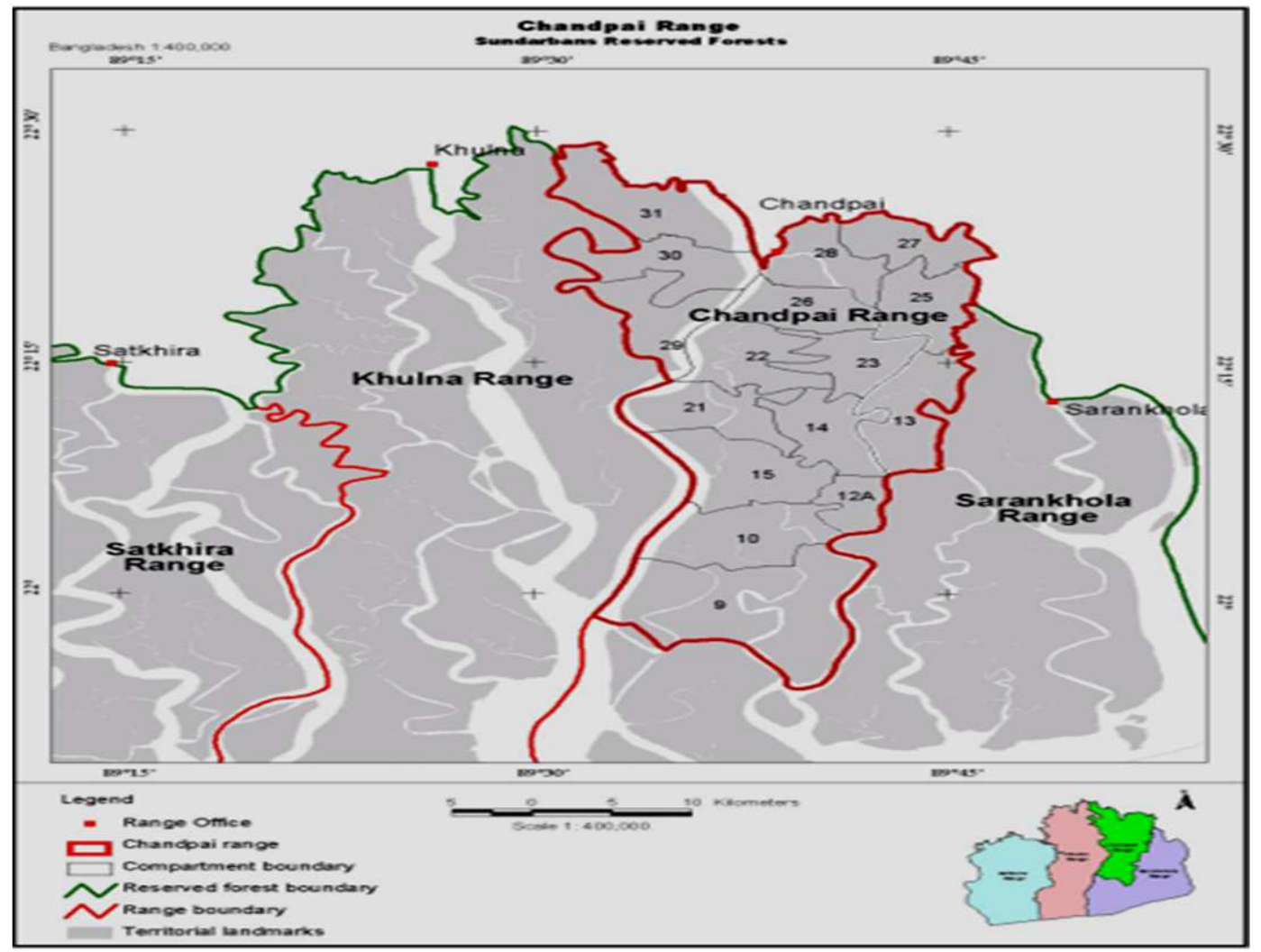

Figure 3. Map showing the location of the numbered compartments within the Chandpai area, and the position of this area relative to other parts of the Sundarbans in Bangladesh (darker shaded area). 
Among the three compartments, compartment number 26 was selected as an area highly affected by top-dying, where most of the trees were affected severely. Compartment 26 had pronounced human activities, and also in places is undergoing rapid housing development involving extensive construction activities due to the presence nearby of the Range HQ office in Chandpai. Compartment number 28 was selected as a moderately affected area. This compartment has various human activities including boat making grounds, football-playing grounds, and cattle-grazing fields, all types of major soil erosion, a moderate amount of construction activities and the presence of communities of fishermen. Compartment number 31 was chosen as being relatively little affected by top-dying disease. Of the three chosen compartments, the nearest compartment to Mongla port is compartment 31, with comparatively modest human activities, but which nonetheless involve clear-cutting of natural vegetation, replanting with other species rather than mangrove or other native species, all types of soil erosion, and construction activities present. Within each of the three compartments, detailed observations of the regeneration and sampling of soil and water took place within three $20 \mathrm{~m} \times 20 \mathrm{~m}$ plots, chosen to reflect a range of top dying intensities (High, medium and Low for that area). The sampling was conducted in a randomised block design, in that a plot was sited within a particular top-dying intensity block, but the precise location of that plot was randomised so as not to bias the detailed data collection. Thus in total nine plots were sampled, representing a range of top-dying intensities. Intensive field data collection was made among these nine selected plots. Observations were performed from observation towers during low and high tides, also traversing the forest floor and vegetation on foot, as well as using a speed boat, trawlers, country-boats, and a launch as required to gain access. All sampling was accompanied by Deputy Rangers, Foresters, and Forest guards armed with a rifle from the local office, Chandpai rang, Bangladesh Forest Department, to prevent a fatal attack by a Bengal tiger (Panthera tigris).

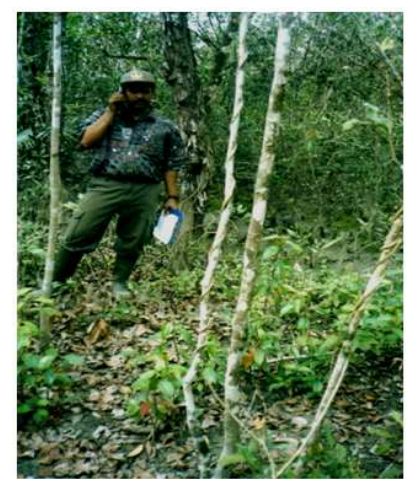

Figure 4. Photograph showing the Sundarbans forest trees and understory vegetation. The adult trees behind the author are of Heritiera fomes. The forest floor shows dead leaves from trees affected by top-dying.
Fieldwork was performed in October, 2003 to March, 2004. Locations of sampling points were determined using a Global Positioning System with a precision of 5-10 m (Table 2.1). For one typical plot, in compartment 31, the altitude was recorded as $4.4 \mathrm{~m}$ above sea level.

\subsection{Vegetation Recording Methods in the Field}

Within each of the nine $20 \mathrm{mx} 20 \mathrm{~m}$ plots, each adult tree was assessed for three parameters. The diameter at $1 \mathrm{~m}$ height was recorded (in $\mathrm{cm}$ ) by using a measuring tape or slide callipers depending on girth. The tree height to the top of the crown was determined mainly by ocular estimation but some heights were checked by using Clinometers at a set distance of $20 \mathrm{~m}$ to test the accuracy of such ocular estimations. Finally, the status of the tree in respect of the amount of top-dying was assessed by using a four point qualitative scale of intensity, namely; not affected, little affected, moderately affected or highly affected by top-dying. This was later expressed as a semiquantitative or rank scale of 0 to 3 respectively, so that a median rank value could be calculated and used as an index of top-dying intensity in that plot.

After that, the total number of seedlings (individuals of the tree species $<1 \mathrm{~m}$ tall), and saplings (young trees $>1 \mathrm{~m}$ tall with a diameter of trunk of $<10 \mathrm{~cm}$ ), were counted within the plots. Care was taken to ensure that trees, saplings and seedlings were not counted more than once or missed in the counting process. After recording, adult trees were marked with white chalk to segregate those marked trees from other trees, seedlings and saplings; red paints were applied to all seedlings and saplings as they were recorded.

\subsection{Soil and Water Sampling Methods}

As stated above, from the three selected compartments, a total of nine plots of $20 \mathrm{~m}$ x $20 \mathrm{~m}$ were selected. From each of these plots, seven soil samples were collected; one from the centre of the plot, four (one each) from all the corners, and two from the middle sides of the plot. Therefore a total of 63 soil samples were taken. Also nine water samples were collected from nearby rivers, creeks or channels, one from the area of each of the sampled plots.

Soil samples were collected from $0-30 \mathrm{~cm}$ soil depth by using a stainless steel spatula and steel cylinder $(d=5.25 \mathrm{~cm})$, and all soil samples were kept in sealed plastic bags. Water samples were collected directly in precleaned plastic-containers.

Marking and labelling was performed with a detailed description of the selected sampling site on both the soilcontaining plastic bags and water containers, and preserved in portable coolers until arrival at the laboratory at Dhaka University for initial chemical analysis. This field sampling method followed the W.H.O, U.K, and E.P.A systems of standard laboratory and field sampling principles, rules and regulations. Rainfall for the area during sample collection 
was not notably different from the respective monthly averages for the Sundarbans of recent years (Awal, 2007); there was no heavy intensity of rainfall within one month before sampling.

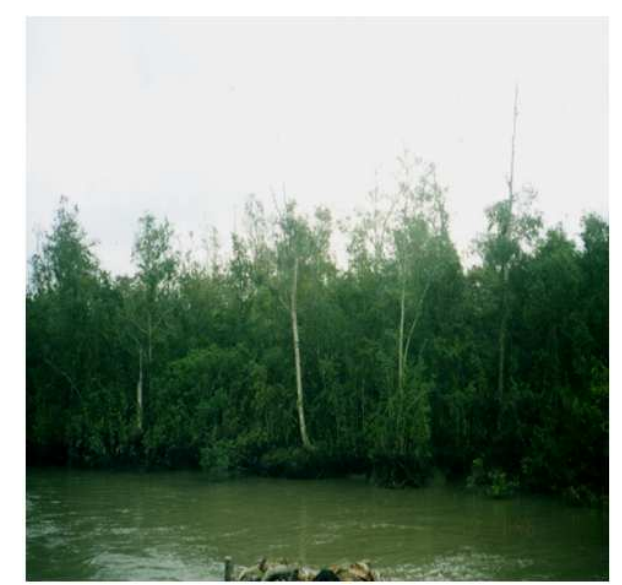

Figure 5. Photograph showing the Sundarbans forest, near compartment number 31, taken from one of the water channels. Note the evidence of top-dying in some of the trees.

Top dying is therefore seen to occur in the entire area of the Sundarbans, but concentrated in the central and northern part. Gibson (1975), on the basis of a visit to the Sundarbans during April 1975 noted that top dying of Sundri had become increasingly serious, particularly in the north-eastern region. He noticed top dying generally in older trees, but it was found at all ages beyond the sapling stage. He reported the disease as most severe in the trees growing on the banks of channels. The incidence of epicormic branching and formation of adventitious crowns in the older mature stands has been reported as high at Chandpai while it was hardly noticeable in the younger or immature stands at Kalabogi (Balmforth, 1985).

The incidence of top dying varies considerably within a block or a compartment. Severely affected areas may be in compartment centres as in the case of the compartments 23 , 26 , and 28 or may be quite inland e.g. inland to the north of Kotka in compartment 6 or along the bank of rivers, e.g. on the eastern side of the Passure river in compartment 45 of Kalabogi, along the Sibsa river, and east of Kalabogi along the Hatdura canal in compartment 33 (Chaffey et al., 1985). Chaffey et al., (1985) reported the results of their survey in randomly located sample units of the Sundarbans during 1983-84, finding that $18 \%$ Sundri of $5 \mathrm{~cm}$ d.b.h class and above were defective.

The status of natural regeneration of Sundri in the Sundarbans for the period 1972 to 1986 has been found to be reasonably consistent and satisfactory. An inventory by Chaffey et al., (1985) revealed that there were about 45.2 million top dying trees in the Sundarbans of which 20 million had more than $50 \%$ of their crown affected by top dying. If it is decided to fell trees having more than $50 \%$ of their crown affected by top dying, which is currently being proposed by the Bangladesh Government, then about 20 million Sundri trees might have to be removed from
Sundarbans, which is not sensible. Before carrying out such an operation on the Sundarbans ecosystem, all possible adverse effects must be taken under critical consideration to save all the species. If all affected Sundri trees were removed from Sundarbans, then the whole forest ecosystem might be lost (Personal observation, 1993-1998).

According to Curtis (1993), having a canker or stagheaded condition on Sundri of above 132 years is quite acceptable, because catabolism naturally exceeds anabolism in old age. This is true for most of the tree species. Moreover, the extensive enumeration data provided by Chaffey et al., (1985) did not show such a pattern either in Sundarbans in general or in the Sundri dominated areas; there are only a few mature Sundri of the above age class which were found to be affected by top dying. The highest percentage of top dying Sundri laying in the $5 \mathrm{~cm} . d . b . h$ class, and this percentage gradually reduces and becomes quite insignificant in trees of $20 \mathrm{~cm}$. d.b.h. It is, therefore, suggested that top dying is not associated with over-maturity and old age. Most of the Sundri trees occupy the upper canopy, where scattered tops and branches of Sundri may be broken by abiotic factors such as atmospheric drying, oxidation and biotic infestation, pathogens and bacterial attacks. Only a limited number of tops and branches of Sundri are likely to be killed in these ways. But in the Sundarbans, trees with quite a few meters of dead tops and branches are seen; only rarely is the whole tree found dead. Moreover, the large proportion of Sundri having d.b.h $5 \mathrm{~cm}$ and above is unlikely to be affected by cyclones, except the exposed once on the banks of the rivers. Hence, cyclone damage as a main cause of top dying of Sundri is also ruled out.

Direct evidence on the causes of death of trees due to the top dying and its mechanism, particularly in the Sundarbans, is of course desirable but to the present there are hardly any such studies which directly explain the cause of top dying as well as the decline of Sundri from the Sundarbans (Rahman, et al., 1995). Since Sundri is one of the main trees in the Sundarbans, and its loss is therefore of significant detriment to the area, the possible causes of this top dying and the evidence supporting such hypotheses are presented in more detail in sections $1.3 ; 2.5$.

\section{5. Possible Causes of Top Dying of Trees}

Various authors have reported the top-dying of Sundri trees in the Sundarbans at different times, notably Toup (1921), Curtis (1933), Forestal (1960), Gibson (1975). On the basis of their observations, these and other authors have at various times suggested several possible hypotheses to explain the cause of the observed top-dying. The several suggested mechanisms, and the evidence available to support each of them, will now be presented.

\subsection{Changed Water Flow and Increased Salinity}

A wide range of arguments had been put forward concerning edaphic changes in Sundarbans. These included 
reduction in flow of fresh water throughout the Sundarbans because of withdrawal of water at Farakka Barrage and resultant increase in soil and water salinity (Shafi, 1982), reduction in siltation (Chowdhury, 1984), increase in siltation (Sattar, 1977), etc. These edaphic changes have been suggested to be responsible for top dying. It may be noted that most of the suggestions were not based on experimental data, for example Banik (2000). Chowdhury (1984) stated that the reduction of fresh water discharges through the Sundarbans was due to (a) the diversion of the upstream Ganges water and (b) more use of upstream water for irrigation and industrial use. Previously the rivers of the area were very active and used to lay freshly deposited silts on top soil every year where Sundri would survive well. But with the reduction in discharge of fresh water, silt carrying capacity of the river has also been reduced. Previously these areas were well drained at ebb tides but now due to change in river regime due to the Farakka barrage, the drainage patterns including flow characteristics have been changed. Consequently the trees are becoming thinner and shorter. Sundri (Heritiera fomes) lacks the ability to exract fresh water from salt water at even a relatively low salt concentration (Hoffman et al., 1986). Balmforth (1985), based on the report of Chaffey et al., (1985), stated that the primary cause of Sundri top dying was the increase in soil salinity. Withdrawal of Ganges water at Farrakka because of the dam construction in 1976 was, in his opinion, one of the possible causes for the increase in salinity in the Sundarbans. Balmforth's statement regarding the causes of Sundri top dying due to an increase in salinity was, however, not supported by his data. Moreover, the data presented by Chaffey et al., (1985), from examined soil samples collected from 20 sites including top dying and healthy Sundri areas in the Sundarbans, are not in agreement with Balmforth's statement, nor with the conclusion of Chaffey et al., (1985) themselves. These authors had suggested that soil salinity was higher on sites affected by top dying than on unaffected sites, and that therefore an increase in soil salinity is an important factor in the onset of top dying. However, severely affected top dying areas are, in fact, distributed in slightly saline to non-saline zones as presented by Chaffey et al. (1985). Thus a total of $18 \%$ of Sundri trees with d.b.h above $5 \mathrm{~cm}$ had been affected by top dying of Sundri in Sundarbans (Chaffey et al., 1985). Only a very small number of top-dying affected Sundri were present in the salt water zone (Chaffey et al., 1985); $13-15 \%$ in moderately salt water zone, $21-24 \%$ in salt water zones and $25-47 \%$ in the fresh water zone respectively. This contrast with results of Ismail (1987), who stated that soil salinity was higher on sites affected by top-dying than on unaffected sites, suggesting that soil salinity is an important factor in the onset of top dying. Sattar (1977) inferred that mortality of Sundri is possibly due to edaphic changes such as heavy siltation, increase in salinity, less flooding by fresh water, and alteration in the frequency and duration of inundation. However, the decline of more salt tolerant species suggests that the cause of decline of the Sundri is not primarily due to insufficient fresh water flow during the dry season. Christensen (1984) stated that salinity may not be a direct cause of top dying but is an indicator of many geochemical processes that have an impact on living organisms (e.g. by affecting nutrient availability). Hassan (1988) provided data on soil and water salinity of a number of sites in the Sundarbans. He also studied the effect of salinity of Sundri seedlings in a simulated experiment. The data on salinity was compared with those of Chaffey et al., (1985). It was observed that the top dying did not show any consistent relationship with the salinity. Hassan (1988) reported that soil salinity in the Sundarbans varies between less than 2000 micro mhos to more than 4000 micro mhos, which rises up to about 6000 micro mohs during the lean period in April. Hassan (1988) also observed that Sundri top dying did not show any consistent relationships with salinity. Moreover, regeneration and survival of Sundri seedlings did not show any change due to water salinity variation between the range 1,000 to 49,000 micro mhos under experimental conditions. Therefore, Hassan et al., (1984) provided a detailed report on soil and salinity of the Sundarbans in relation to top- dying, regeneration and survival of Sundri. They did not observe any consistent relationships between top dying and salinity. Regeneration and survival of Sundri seedlings also did not show any relationships to the salinity variation between 10,000 to 49000 micro mohs under simulated conditions (Hassan, et al., 1984).

Accordingly Shell and Ross (1987) studied the $\mathrm{Na}+$ and $\mathrm{K}+$ levels in Sundri tissues and found that: (a) the $\mathrm{Na}+/ \mathrm{K}+$ ratios in the tissues of healthy trees appear to be related to the salinity of their local environment; (b) the average percentage of $\mathrm{Na}+$ and $\mathrm{K}+$ was not significantly different in healthy and dying Sundri trees; (c) though some link was indicated between top dying and ionic balance in plant tissue, it was not possible to resolve the causal factor and its effect. According to Lugo and Snedaker (1974), gross primary productivity of mangroves increases with the availability of fresh water. The fresh water input to the estuary is associated with physical, chemical, geological and biological melange, fauna and flora of the estuary / coastal zone. This input tends to enrich the sites (Snedaker et al., 1977). Imam (1982) noted that a system analysis and simulated studies on the ecology of mangrove forests in Florida, USA, had demonstrated that terrestrial water plays a vital role in the development of mangrove biomass, which in turn reflects the gross photosynthesis. It has been construed that both mangrove zonation and vigour are functions of nutrient availability rather than salinity alone. On the basis of the above findings Sheil and Ross (1987), concluded that these observations are compatible with a pathogenic cause of top dying as forwarded by Rahman et al., (1983; see next section). This means that in their opinion salinity is not the causal factor for the top dying (Awa, 2007).

More recent research on the association between salinity and top dying of Hetiera fomes has concluded that it is not 
the causal factor previously thought. Hassan et al. (1990) suggested that there is no relationship between salinity and top dying of Sundri, and data of Rahaman et al. (2003), where soil salinity was estimated in terms of the level of sodium $(\mathrm{Na})$ and electrical conductivity, revealed that there is no significant variation in the mean value of $\mathrm{Na}$ and $\mathrm{EC}$ in soil of the Sundarbans.

According to Gupta et al. (1986), reporting on the salt tolerance of some tree species at the seedling stage, the salinity ranges which prevail in the Sundarbans are tolerable even to some mesophytes such as Eucalyptus camaldulensis and Acacia nilotica. This observation contradicts with the inference that a species such as Sundri should be seriously affected by the salinity observed. Moreover, without a governing cause top dying could not merely increase with time, as suggested by Chaffey et al. (1985), indicating that salinity alone can not be the cause of top dying of Sundri.

\subsection{Altered Pneumatophores}

Chaffey (1985) reported that reduction in the number of lenticels on the pneumatophores might be associated with top dying of Sundri. Accordingly, a study was carried out in which the numbers of lenticels were counted under a magnifying lens on 90 sq. $\mathrm{cm}$ area of the pneumatophores of nine top dying and nine healthy Sundri trees, selected randomly from relatively fresh water zone at Burigolini. Actually, the results indicated that there was no relation between the number of lenticels on the pneumatophores and the top dying.

\subsection{Soil Factors}

According to Siobhan (1973), who compared the chemical and physical properties of triplicate soil samples collected from severely affected top-dying and healthy Sundri areas, there was little difference in chemical properties of the two regions; however, the sand component in the healthy Sundri area was much higher than in top dying area. No consistent difference in chemical properties was observed but the sand component in samples from areas of healthy Sundri was much higher than that of top dying affected areas. According to Ismail $(1988,1987)$ when a pronounced dry season is followed by heavy showers, some critical nutrients are washed away. He argues that a poorer-quality forest in the Sundarbans is due to the loss of critical nutrients by sporadic heavy showers of recent years and not due to high salinity. The effect of individual ions present in saline soil, particularly sodium, has been studied by a few workers. The most important effect of sodium may be dispersing the soil and preventing root ramification (Plice, 1949) but very little is known about the effect of chloride ions (Francy et al., 1959). Blanquet (1932) stated that sodium chloride is the determining factor in the distribution of plant species and communities on low level coasts. In general, salinity is a controlling factor in the floristic ecology of the Sundarbans (Snedakar, 1984). The soil analysis by Chaffey et al., (1985) showed that soils of a number of sites contain lime which is a normal component of the Himalayan alluvium. Islam $(1992,1982)$ mentioned that the presence of lime would be expected to alleviate to some extent the adverse effect of high levels of soluble sodium. Soil analysis did not show that lime is a factor in the presence or absence of Sundri top dying. No evidence was found by Chaffey et al., (1985) of acid sulphate which adversely affected the plant growth. No evidence of acid sulphate was found by Ismail (1987) which adversely affected the plant growth. The results of soil analysis strongly indicated a relationship between the presence of top dying and the concentration of $\mathrm{pH}$ in the soil profile however (Ismail, 1987).Boron deficiency is known to cause large scale dieback in Forestry (Bangash and Gardiner, 1985) but the saturation extract analyses by Chaffey et al., (1985) show very low boron levels (below $0.5 \mathrm{ppm}$ ) in some sites. These low levels of boron are not correlated with the incidence of top dying (Awal, 2007).

Heavy metal concentrations in the Sundarbans soil have not yet been measured systematically, despite the potential contamination from effluent discharged, as discussed on section 1.3. The information of heavy metals in the soil with possible impacts upon the Sundarbans Reserved Forests is scanty (Awal, 2007). All kinds of wastes or pollutants dumped into the rivers can produce a change of physical characteristics of the soils and ecosystems (Awal, 2007). Mangrove plants are generally considered as filters for many pollutants, but such materials can be passed along a food-chain, ultimately with a potential of attaining unacceptable high levels in species consumed by humans.

\subsection{Entomological Causes}

As the heart rot fungi decay the wood and beetle larval tunnels increase, the commercial value of the wood is largely diminished (Chowdhury and Baksha, 1983). A study of the state of health of the cable, anchor, and nutrition roots of healthy and top dying Sundri trees was conducted at Sutarkhali. The results showed no significant difference in the root of healthy and top dying trees (Singh, 1986, Chaudhury, 1968; and Gibson, 1975). Chowdhury (1973) observed plenty of Chrysocroa species in the twig crotches of dead and dying Sundri trees in the compartment Nos.26, 28, 29, 30 and 31 at Marapassur in adjacent areas. The role of Chrysocroa species in the initiation of top dying of Sundri was subsequently studied and reported by Chowdhury and Baksha (1983). For the study, three diseased trees at various stages of attack and one healthy tree were selected at random in each of compartments 31 , 32 and 46 representing relatively fresh water, moderately saline water and highly saline water zones respectively. The trees were felled and split thoroughly from top to bottom. The position of the dead branches, larval tunnels and the portions damaged by heart rot were recorded. There were in all 19 dead branches of which the relative positions of 15 branches were from the sites of the larval tunnels and heart rot. Heart rot was observed in 11 out of 12 trees. According to them, it became obvious that larval 
tunnel and /or heart rot did not have any contiguity with the dead branches. Even the tissues at the base of these branches were found to be healthy and the entrance holes of the larvae were healed up. They concluded that Chrysocroa species. did not have any role in the initiation of top dying of Sundri (Chowdhury and Baksha, 1983).

\subsection{Pathological Causes}

Pathological studies on top dying of Sundri were conducted by Rahman et al. (1983, 1986). Based on these and other studies conducted so far (reviewed in Rahman et al., 1986) there does not appear to an association between pathological factors and top-dying. According to Rahman et al. (2001), a precise description of symptoms of any plant is important for further study leading to disease prevention. The same is true in case of top dying of Sundri as well. Therefore, trees were labelled in each of the damage categories (Rahman et al., 2001). After that the labelled trees were observed to identify the symptoms of top-dying on the various branches at the time of recording within the selected plots. Subsequently, observations at monthly intervals were recorded of the symptoms of top dying on the branches and progressive changes were recorded for 12 months. In this way Rahman et al. (2001) tried to identify the first symptom expression and its progressive changes over time. But there is a big gap between primary and secondary causes of infection and symptoms for each particular Sundri tree. There is no scientific proof that pathogens are causing this top dying of Sundri. Many of the scientists had made technical comments about pathological studies, but they did not find any scientific base for the correlation between pathogens and top dying. Previous research had tried to find out the causal agents of top dying of Sundri, and tried to determine the infection-biology of the causal factors (pathogens) for top dying of Sundri (Hartung et al. 1998; Chowdhury and Baksha, 1983, 1986; Rahman et al. 1983). Rahman et al. (2001) also tried to find out the biotic and abiotic factors responsible for aggravating the top dying disease of Sundri. However, they failed to find out the real cause of top dying of Sundri. Hartung et al. (1998) reported their findings about the putative biotic disease agents of top dying of Sundri in the Sundarbans. For the study, they collected 20 samples of wood, bark, and leaves from compartment 19, $22,26,32$, and 39 in 1997 . This study was conducted for the isolation of bacteria, and eight types of bacterial colonies were recorded. The colour of bacteria colonies were white, yellow, red, white-yellow, yellow-white, yellow-brown, grey-white, shiny- white, etc. There was no yield of bacterial colonies from wood tissues taken from un-affected Sundri trees (3 samples). Samples of affecteddead-standing Sundri (2 samples), 4 unaffected wood samples of other tree species ( 2 from Gewa, 1 from Passur, and 1 from Goran) were taken. Out of the 6 to 8 types of bacterial colonies, two isolates have been identified as Arthrobacter nicotianae and Pseudomonas species due to their sequence homologies in a PCR assay. Both the species of bacteria were isolated from samples of severely top dying affected living Sundri trees. The bacterial species showed phytopathogenic ability in a bioassay. The authors concluded a close association of phytopathgenic bacteria with top dying disease of Sundri (Hartung et al., 1998). But a through search of literature does not reveal any association of $A$. nicotianane with any other tree disease problem anywhere in the world. Moreover the data presented do not provide enough evidence of consistent association of Pseudomonas species with top dying of Sundri wood.

\subsection{Gall Cankers}

Occurrence of cankers on top dying Sundri trees has been recorded by Curtis (1933), Chowdhury (1973). It may be noted that the cankers on apparently healthy trees could be an early stage of deterioration and death of twigs or branches. Rahman et al. (1983) reported that a fungus identified as Botryosphaeria ribis was consistently isolated from Sundri canker. An early stage of gall canker develops on Sundri saplings. To investigate the proper cause of canker, the fungi were isolated from the bark and woody tissues of Sundri Canker samples following standard phytopathological method (Booth, 1971). One fungus was isolated as no. BFRI 230 and identified as Botryosphaeria ribis (Grosenb and Duggar), and occurred consistently. A number of other fungi were obtained only sporadically and hence disregarded.

The distribution and severity of perennial canker development on healthy and dying twigs, branches and stems of Sundri were studied at Sutarkhali Sarbotkhali, Kalabogi and Mankiduania (Rahman et al., 1983, 1986). It was found that there were top dying trees which had virtually no canker. The results suggested that there existed an association between top dying of Sundri and twigs and branches with gall canker in nearly $50 \%$ of the top dying Sundri trees surveyed, but in some trees the top dying condition was independent of gall canker development. There is therefore no conclusive link between the canker and top dying.

\section{Results Section}


Table 1. Comparison of tested heavy-metals element concentrations (ppb) in Sundarbans. (Key to other sources: PL= Peach leaf reference material used; M in I = Ministry of India, 1987, Nayak, 1993; Nig = Nigerian information (AJEAM-RAGEE, 2004); GGC = Generation for Good chemistry \{Mallinc Kradt Chemicals; HNo(6623)\}; England and Wales=(E.W); ES= Estuarine sediments reference material; SRM=Standard Reference Material). Compareable data could not be found for all elements.

\begin{tabular}{|c|c|c|c|c|}
\hline Element & Sundarbans (Present data) & & Values reported elsewhere & \\
\hline $\begin{array}{l}\text { Identified heavy-metals in } \\
\text { Sundarbans. }\end{array}$ & $\begin{array}{l}\text { Minimum mean values (in } \\
\text { ppb) }\end{array}$ & $\begin{array}{l}\text { Maximum mean values } \\
\text { (in ppb) }\end{array}$ & $\begin{array}{l}\text { Minimum mean values (in } \\
\text { ppb) }\end{array}$ & $\begin{array}{l}\text { Maximum mean values } \\
\text { (in ppb) }\end{array}$ \\
\hline $\mathrm{Al}$ (Aluminium) & 15.62 & $37,570.00$ & (Min I): 3.13 & $(\operatorname{Min} I) 46.10$ \\
\hline As(Arsenic) & (-) 0.57 & 10.06 & $\begin{array}{l}0.00006(\mathrm{Pl}) \\
0.00005(\mathrm{Nig})\end{array}$ & $\begin{array}{l}\text { (ES): } 0.0116 \\
0.00111(\mathrm{Nig})\end{array}$ \\
\hline B(Boron) & 4.81 & 77.21 & 0.029 (SRM) & (GGC): 10.00 \\
\hline $\mathrm{Ba}$ (Barium) & 0.41 & 141.80 & $\begin{array}{l}0.124(\mathrm{Pl}) \\
0.011(\mathrm{E} . \mathrm{W})\end{array}$ & $\begin{array}{l}(\mathrm{GGC}): 1.00 \\
2.973 \text { (E.W) }\end{array}$ \\
\hline Bi(Bismuth) & (-) 0.01 & 0.74 & - & (GGC): 10.00 \\
\hline $\mathrm{Ca}($ Calcium $)$ & 44.77 & $17,600.00$ & 0.00005 (E.W) & (GGC):200.0 \\
\hline $\mathrm{Cd}(\mathrm{Cadmium})$ & 0.14 & 1.62 & $\begin{array}{l}0.002 \text { (Thai) } \\
\text { (Pl)0.00003 } \\
\text { (Min I):0.0003 }\end{array}$ & $\begin{array}{l}0.016 \text { (Thai) } \\
\text { (ES): } 0.0004 \\
\text { (Min I): } 0.014\end{array}$ \\
\hline $\mathrm{Co}($ Cobalt $)$ & 5.93 & 143.6 & -(Min I): 0.003 & $\begin{array}{l}\text { (ES): } 0.0105 \\
\text { (Min I): } 0.026\end{array}$ \\
\hline Cr(Chromium) & 3.14 & 114.90 & 0.0000016 (Nig) & $\begin{array}{l}\text { (ES): } 0.076 \\
0.000017 \text { (Nig) }\end{array}$ \\
\hline $\mathrm{Cu}$ (Copper) & 1.85 & 43.76 & $\begin{array}{l}0.131 \text { (Thai) } \\
\text { (Pl): } 0.004 \\
\text { (Min I): } 0.006\end{array}$ & $\begin{array}{l}0.260 \text { (Thai) } \\
\text { (ES): } 0.018 \\
\text { (Min I): } 0.086\end{array}$ \\
\hline $\mathrm{Fe}$ (Iron) & 25.82 & 248200.0 & $\begin{array}{l}16.00 \text { (Thai) } \\
\text { (PL): } 0.218 \\
\text { (Min I): } 5.30\end{array}$ & $\begin{array}{l}48.00 \text { (Thai) } \\
\text { (Min I): } 52.00\end{array}$ \\
\hline Hg (Mercury) & $(-) 1.43$ & 83.30 & $\begin{array}{l}0.029(\mathrm{Min} \mathrm{I}) \\
(\mathrm{PL}): 0.00003 \\
0.000023(\mathrm{Nig})\end{array}$ & $\begin{array}{l}0.089 \text { (Min I) } \\
(\mathrm{ES}): 0.00007 \\
0.03(\mathrm{Nig})\end{array}$ \\
\hline In(Indium) & 0.15 & 8.84 & 0.00005 (E.W) & - \\
\hline K(Potassium) & 186.50 & 7495.00 & - & - \\
\hline Mg(Magnesium) & 5.14 & 18280.00 & - & $(\mathrm{GGC}): 10.0$ \\
\hline Mo(Molybdenum) & 0.20 & 26.15 & $\begin{array}{l}\text { (PL): } 0.00006 \\
0.000008 \text { (Nig) }\end{array}$ & $0.00005(\mathrm{Nig})$ \\
\hline Mn(Manganese) & 0.70 & 698.00 & $\begin{array}{l}\text { (PL): } 0.098 \\
\text { (Min I): } 0.005\end{array}$ & $\begin{array}{l}\text { (ES): } 0.375 \\
\text { (Min I): } 0.44\end{array}$ \\
\hline $\mathrm{Na}$ (Sodium) & 75.83 & 6065.00 & $\begin{array}{l}\text { (PL): } 0.024 \\
0.3 \text { (UK) }\end{array}$ & $\begin{array}{l}(\mathrm{GGC}): 500.0 \\
-\end{array}$ \\
\hline Ni(Nickel) & 7.58 & 1127.00 & $\begin{array}{l}\text { (PL): } 0.0007 \\
\text { (Min I): } 0.008\end{array}$ & $\begin{array}{l}\text { (ES):0.032 } \\
\text { (Min I): } 0.04 \\
\text { (GGC):5.00 }\end{array}$ \\
\hline P(Phosphorus) & (-) 62.83 & 1094.00 & - & $(\mathrm{GGC}): 20.0$ \\
\hline $\mathrm{Pb}$ (Lead) & 0.32 & 34.19 & $\begin{array}{l}0.032 \text { (Thai) } \\
\text { (PL): } 0.0009 \\
\text { (M in I): } 0.0015\end{array}$ & $\begin{array}{l}0.079 \text { (Thai) } \\
\text { (ES):0.0282 } \\
\text { (Min I): } 0.024\end{array}$ \\
\hline $\mathrm{Rb}$ (Rubidium) & 0.15 & 76.19 & $\begin{array}{l}\text { (PL): } 0.0197 \\
0.02 \text { (E.W) }\end{array}$ & 0.0209 (SRM) \\
\hline $\mathrm{Sb}$ (Antimony) & $(-) 0.23$ & 2.92 & $\begin{array}{l}0.00003 \text { (Nig) } \\
0.0005 \text { (E.W) }\end{array}$ & $\begin{array}{l}0.000107 \text { (Nig) } \\
0.00002 \text { (SRM) }\end{array}$ \\
\hline Sc(Scandinium) & $(-) 1.15$ & 8.98 & 0.0003 (E.W) & $0.00004(\mathrm{SRM})$ \\
\hline Se(Selenium) & $(-) 2.98$ & 5.71 & $\begin{array}{l}\text { (PL): } 0.00012 \\
0.00003 \text { (Nig) }\end{array}$ & $\begin{array}{l}0.00013 \text { (SRM) } \\
0.0014 \text { (Nig) }\end{array}$ \\
\hline $\mathrm{Si}$ (Silicon) & $(-) 2033.0$ & 3978.00 & - & $(\mathrm{GGC}): 50.0$ \\
\hline Sn (Tin) & $(-) 0.41$ & 9.68 & $<0.0002(\mathrm{SRM})$ & $(\mathrm{GGC}): 10.0$ \\
\hline $\mathrm{Sr}$ (Strontium) & 0.18 & 44.17 & $(\mathrm{PL}): 0.053$ & $\begin{array}{l}(\mathrm{GGC}): 1.00 \\
0.057(\mathrm{SRM})\end{array}$ \\
\hline Ti (Titanium) & 1.37 & 1350.00 & 1.0 (E.W) & $(\mathrm{GGC}): 0.30$ \\
\hline $\mathrm{V}$ (Vanadium) & 0.09 & 42.41 & $\begin{array}{l}\text { (PL):0.0004 } \\
0.004 \text { (Nig) }\end{array}$ & $\begin{array}{l}\text { (ES):0.094 } \\
0.298(\mathrm{Nig})\end{array}$ \\
\hline Y (Yttrium) & 0.03 & 16.69 & $\overline{(\overline{P L})}: 0.0179$ & $\begin{array}{l}27000.00(\mathrm{E} . \mathrm{W}) \\
(\mathrm{ES}): 0.138\end{array}$ \\
\hline $\mathrm{Zn}(\mathrm{Zinc})$ & 2.30 & 112.60 & $\begin{array}{l}\text { (Min I): } 9.64 \\
0.029 \text { (Thai0 }\end{array}$ & $\begin{array}{l}\text { (Min I):56.2 } \\
0.088 \text { (Thai) }\end{array}$ \\
\hline
\end{tabular}




\section{Discussion}

Each individual tree, when it was being recorded, had an estimate made of the severity of top-dying affecting it. In order to be able to calculate an average value per plot, these qualitative assessment categories of severity were assigned a numerical score of 0--3 (table 1.0).

Table 2. Average index scores of the severity of top-dying per tree for each of the plots sampled.

\begin{tabular}{llll}
\hline Compartment / Plot & $\mathbf{2 6}$ & $\mathbf{2 8}$ & $\mathbf{3 1}$ \\
\hline 1 & 1.88 & 2.51 & 2.00 \\
2 & 1.85 & 1.57 & 1.78 \\
3 & 1.58 & 1.45 & 1.07 \\
\hline
\end{tabular}

This score was then summed to give an aggregate score which, when divided by the number of trees included, gave an average index score per plot. These values are included in Table 6. It should be remembered that the plots had been selected from within each of the compartments to reflect an apparent increase in severity of top-dying, and the compartments had also been selected to reflect differences in this aspect, so it is not surprising that there appears to be differences in this parameter in the table. However, when this was tested by a 2-factor Analysis of Variance, with Compartment as one factor and Plot as the other, the results were not significant for either compartment and plot $(\mathrm{F}$ compartment $=0.49, \mathrm{df}=2, \mathrm{p}=>0.10 ; \mathrm{F}$ plot $=5.36, \mathrm{df}=2, \mathrm{p}=$ $<0.10$ ), although the result for plots came close to significance. The fact that these results for top-dying did not prove to be significant, despite selection of the compartments and plots to reflect a gradient in the prevalence of top-dying may be because of the limited range of values that the top-dying index could take. Also, further replicates of the number of plots would have probably helped make it more likely that a significant result was achieved. At least the difference between plots in their top-dying severity is believed to be valid despite it not quite being proven statistically, and differences between compartments are also thought to be real, if not detectable in this analysis. Treating the average index scores from Table 2.0 as one variable, the top- dying index can be correlated with the various variables given in Table 3.7 in order to test whether there is any relationship between the incidence of top-dying and parameters such as tree height or bole diameter. Since the average top-dying index is a variable that may not be meeting all the assumptions for a parametric test it is better to use the Spearman's Rank Correlation Coefficient for these analyses. A summary of the outcome for these analyses is given in Table 3.0 below.

None of the growth parameters were significantly related to amount of top-dying, but the percentage of soil moisture content was; the lower the amount of moisture, the greater the top-dying.
Table 3. Outcomes from the analyses using Spearman's Rank Correlation Coefficient of the relationship between severity of top-dying and various parameters of tree structure and growth (Key: NS=p>0.05; $*=p<0.05$ ).

\begin{tabular}{|c|c|c|c|}
\hline $\begin{array}{l}\text { Parameters } \\
\text { comparing with } \\
\text { Top-dying. }\end{array}$ & $\begin{array}{l}\text { Correlation } \\
\text { (r-value, with7df). }\end{array}$ & $\begin{array}{l}\text { Probability } \\
\text { (p-value) }\end{array}$ & $\begin{array}{l}\text { Sig. or } \\
\text { N.S }\end{array}$ \\
\hline Tree height (m) & -0.113 & 0.773 & N.S \\
\hline Tallest tree height (m) & 0.072 & 0.854 & N.S \\
\hline Bole diameter $(\mathrm{cm})$ & 0.067 & 0.865 & N.S \\
\hline Tree density $\left(\mathrm{m}^{2}\right)$ & 0.021 & 0.956 & N.S \\
\hline $\begin{array}{l}\text { Soil Moisture Content } \\
\text { Percentage (M.C. \%). }\end{array}$ & -0.736 & 0.024 & * \\
\hline
\end{tabular}

In order to describe the vegetation structure more fully at each of the location it is desirable not only to record the adult trees but also the potential regeneration of new trees by recording the abundance of seedlings (newly germinated plants) and saplings (young trees less than $10 \mathrm{~cm}$ diameter). This information is presented in Tables 4.0 and 5.0.

Table 4. Frequency of seedlings of all tree species combined in each of the nine plots sampled.

\begin{tabular}{lllll}
\hline Compartment / Plot & $\mathbf{2 6}$ & $\mathbf{2 8}$ & $\mathbf{3 1}$ & Totals \\
\hline 1 & 1261 & 1440 & 625 & 3326 \\
2 & 1326 & 1501 & 1430 & 4257 \\
3 & 1455 & 1575 & 1830 & 4860 \\
Totals & 4042 & 4516 & 3885 & 12443 \\
\hline
\end{tabular}

Table 6. Frequency of saplings (trees in $m$ tall) of all tree species combined in each of the nine plots sampled.

\begin{tabular}{lllll}
\hline Compartment / Plot & $\mathbf{2 6}$ & $\mathbf{2 8}$ & $\mathbf{3 1}$ & Totals \\
\hline 1 & 282 & 228 & 167 & 677 \\
2 & 266 & 172 & 396 & 834 \\
3 & 566 & 215 & 343 & 1124 \\
Totals & 1114 & 615 & 906 & 2635 \\
\hline
\end{tabular}

In order to test whether there is any association between the frequency of seedlings or saplings and the compartment or plot in which they were recorded, a chi-square analysis was performed for the data in each of Table 4.0 and 5.0. The result for seedlings was that $\Sigma \kappa^{2}$ gave a value of 344.7 which was very highly significant $(\mathrm{p}<0.001$, df $=4)$, while the value of $\Sigma k^{2}$ for saplings was 145.9 and was also highly significant $(p<0.001, d f=4)$. Clearly, both sets of data for regenerating trees were highly influenced by location, with clear evidence of a reduction in abundance in sites which had been selected as showing high incidences of top-dying, with least regeneration in Compartment 31 Plot 1 and, particularly with the sapling data, with the greatest numbers of regenerating saplings in Compartment 26 Plot 3.

\section{Final Conclusions}

The overall conclusions from the results presented in this section are that the selection of sites has not produced clear statistical differences in the amount of top-dying evident; 
probably because of the way the data were collected. However, it is believed that there is notable variation between plots and compartments, and certainly this seems to be reflected in the ability of the trees to regenerate. However, the link between top-dying and the size of the trees is not clear, with tree height and diameter not being directly related consistently to amount of top-dying, although moisture content of soil was inversely related. Since the great majority of trees present in all plots is the species Heritiera fomes, this means that the comments above are essentially referring to the response of this species rather than that of any others.

Comparing figures in the table, it would suggest that about two thirds of the elements have concentrations which are elevated compare to other reference sources in the Sundarbans. This would be consistent with the evidence that heavy metals were having an influence on top-dying intensity (Awal, 2007, 2009, 2014). The elements Pb, Sn, and $\mathrm{Zn}$ were highlighted earlier in this discussion, and although not all of them quite reached statistical significance (Awal, 2007), the positive trend linking two of them to top-dying suggests a likely mechanism of influence, namely that greater concentration of the heavy-metal weaken the resistance of the tree to attack by the pathogenic fungi (Awal, 2007, 2009, 20014). This might well be a process that other elements contribute to as well (Awal, 2007, 2009, 2014), but has not been picked out by the analysis as showing a link because of the variability between samples inherent in the data (Awal, 2007). In this respect, the anomaly of the negative relationship indicated for $\mathrm{Sn}$ is harder to explain (Awal, 2007), but a possible process might be an antagonistic response of $\mathrm{Sn}$ and another element(Awal, 2007), so that when Sn is less abundant the other element can have a stronger (deleterious) effect on the trees (Awal, 2007), thus allowing more topdying to occur (Awal, 2007). A further point is that variations in soil $\mathrm{pH}$ from site to site (shown to be significant) will also have a marked effect on the bioavailability of some of these heavy metals (Awal, 2007), and thus perhaps influence top-dying (Awal, 2007).

Table 5. Data on locations of plots, as indicated by Geographical Position System (G.P.S).

\begin{tabular}{|c|c|c|c|}
\hline \multirow{2}{*}{$\begin{array}{l}\text { Compartment. } \\
\text { Number. }\end{array}$} & \multirow{2}{*}{$\begin{array}{l}\text { Plot } \\
\text { Number. }\end{array}$} & \multicolumn{2}{|c|}{$\begin{array}{l}\text { Geographical Position Systems } \\
\text { (GPS) reading. }\end{array}$} \\
\hline & & North latitudes & East longitudes \\
\hline 26 & 1 & $\mathrm{~N} 22^{\circ} 32347^{\prime}$ & E $089^{\circ} 64470^{\prime}$ \\
\hline 26 & 2 & $\mathrm{~N} 22^{\circ} 32977^{\prime}$ & $\mathrm{E} 089^{\circ} 64276^{\prime}$ \\
\hline 26 & 3 & N $22^{\circ} 33820^{\prime}$ & E $089^{\circ} 63504^{\prime}$ \\
\hline 28 & 4 & $\mathrm{~N} 22^{\circ} 36728^{\prime}$ & E $089^{\circ} 66538^{\prime}$ \\
\hline 28 & 5 & N $28^{\circ} 36378^{\prime}$ & E $089^{\circ} 66918^{\prime}$ \\
\hline 28 & 6 & N $22^{\circ} 36878^{\prime}$ & E $089^{\circ} 66291^{\prime}$ \\
\hline 31 & 7 & $\mathrm{~N} 22^{\circ} 42821^{\prime}$ & E $089^{\circ} 57611^{\prime}$ \\
\hline 31 & 8 & N $22^{\circ} 42715$ & E $089^{\circ} 580440^{\prime}$ \\
\hline 31 & 9 & N $22^{\circ} 44201^{\prime}$ & E $089^{\circ} 58219^{\prime}$ \\
\hline
\end{tabular}

The present data also contribute evidence regarding other suggested hypotheses for the causes of top-dying (outlined in the sections $1 \& 2$ ). The non-significant relationship between soluble or exchangeable $\mathrm{Na}$ (Awal, 2007) and the amount of top-dying (Awal, 2007), or with the amount of tree growth (Awal, 2007), strongly suggests that the hypothesis of salinity changes being the cause of top-dying is not correct (Awal, 2007, 2009, 2014). However, the data on moisture content percentage do indicate that the Sundarbans has lower values than many other mangrove forests (Awal, 2007), and the values obtained are rather low even compared to others obtained from the Sundarbans (Faizuddin, 2003). This suggests that the Sundarbans is experiencing problems with its water supply (Awal, 2007, 2014), which may be linked (Awal, 2007), at least in part, to the construction of the Farraka barrage ((Awal, 2007; FAO report, 1984). If the drainage system of the water basin is poor, the tendency towards more acidic soil and water may increase (Awal, 2007; Christensen, 1984).

The evidence presented in this thesis therefore points not to one specific factor as being entirely responsible for the increasing amount of top-dying (Personal observation staying in Sundarbans as Head of East Wildlife Sanctuary from 1993-1998, Awal, 2007, 2009, 2014), but rather to a combination of factors(Personal observation staying in Sundarbans as Head of East Wildlife Sanctuary from 19931998, Awal, 2007, 2009, 2014); changing water supply and heavy metal contamination in particular(Personal observation staying in Sundarbans as Head of East Wildlife Sanctuary from 1993-1998, Awal, 2007, 2009, 2014), coupled with possible $\mathrm{pH}$ changes, lead to a weakening of the trees(Personal observation staying in Sundarbans as Head of East Wildlife Sanctuary from 1993-1998, Awal, 2007, 2009, 2014), which are then more susceptible to greater attack by pathogens(Personal observation staying in Sundarbans as Head of East Wildlife Sanctuary from 19931998, Awal, 2007, 2009, 2014), and lowered resistance to them by the trees (Personal observation staying in Sundarbans as Head of East Wildlife Sanctuary and also as ACF from 1993-1998, Awal, 2007, 2009, 2014),. This combination of factors is also supported by the comments of the people interviewed, (Personal observation staying in Sundarbans as Head of East Wildlife Sanctuary from 19931998, Awal, 2007, 2009, 2014), who suggested many different factors as the cause as well as implying that the change was gradual by not being able to pick out a specific starting date to the problem (Awal, 2007). This would be precisely the pattern that might be expected where no one factor was solely responsible, (Personal observation staying in Sundarbans as Head of East Wildlife Sanctuary from 1993-1998, Awal, 2007, 2009, 2014), and the combinations of factors might be somewhat different in different areas (Personal observation staying in Sundarbans as Head of East Wildlife Sanctuary from 1993-1998, Awal, 2007, 2009, 2014). Of course, having a number of interlinked factors as believed likely causes of the problem 
makes a solution to the problem more difficult (Personal observation staying in Sundarbans as Head of East Wildlife Sanctuary from 1993-1998, Awal, 2007, 2009, 2014). Some suggestions for ways of alleviating the problems, as well as further research that could be done(Personal observation staying in Sundarbans as Head of East Wildlife Sanctuary from 1993-1998, Awal, 2007, 2009, 2014), are included in the section below.

Although there were only a few individual chemical elements which showed significant correlations with the amount of top-dying (Personal observation staying in Sundarbans as Head of East Wildlife Sanctuary from 19931998, Awal, 2007, 2009, 2014), there was evidence of elevated heavy-metal concentrations of many elements in the Sundarbans (Personal observation staying in Sundarbans as Head of East Wildlife Sanctuary from 1993-1998, Awal, 2007, 2009, 2014), which are likely to contribute to the increase in top-dying observed(Personal observation staying in Sundarbans as Head of East Wildlife Sanctuary from 1993-1998, Awal, 2007, 2009, 2014). There were also significant differences between different areas in the Sundarbans (Awal, 2007), and evidence of water supply problems to the system (Personal observation staying in Sundarbans as Head of East Wildlife Sanctuary from 19931998, Awal, 2007, 2009, 2014). Therefore, it is concluded that several factors are responsible for this increase in topdying, rather than one specific factor only (Personal observation staying in Sundarbans as Head of East Wildlife Sanctuary from 1993-1998, Awal, 2007, 2009, 2014).

\section{Acknowledgements}

My research work was supported financially by the Peoples' Republic of Bangladesh and the Asian Development Bank (ADB), whom I thank. Particular thanks are due to the ADB head office, Manila for their support and help. I thank sincerely Dr. W.G.H. Hale (Principal Supervisor), University of Bradford, UK, Professor Mike Ashmore (Technical Supervisor), University of York, UK and Dr. P.J. Hogarth for their advice and comments on the work; Dr. Ben Stern and the staff at the Analytical Centre, Bradford, for their help with the ICPMS analyses; Professor Sirajul Hoque, Mustafa (lab Technician)and staff at Dhaka University for providing facilities; and staff of the Forestry Service, Bangladesh Government, for field assistance. Moreover I indebted to my beloved parents ( Munshi Aowlad Hossain, Mrs. Ashrafunness), my beloved wife (Dr. Shahanaj Khatun), my beloved son (Munshi Tasneem Redowan), my beloved daughter (Marwa Ashra), my beloved brothers (Munshi Abul Kalam Azad), and (Munshi Abdus Salam) and my beloved 6 sisters (Layla Anjumand Banu (Chandu), Akter Rashida Banu (Turi), Saleha Pervin (Lili), Azmeri Ferdowsi (Dolly), Jannatul Ferdowsi (Polly) and my beloved youngest sister Bedowra Ferdowsi (Jolly), Dr. Shajahan Kabir, NIH, USA, as well as all family members for their inspiration and help.

\section{References}

[1] Awal, M.A. (2007). Analysis of possible environmental factors causing top-dying in mangrove forest trees in the Sundarbans in Bangladesh. PhD thesis, University of Bradford.

[2] Awal, M.A., Hale, W.H.G. \& Stern, B. (2009). Trace element concentrations in mangrove sediments in the Sundarbans, Bangladesh. Marine Pollution Bulletin, 58(12), 1944-1948.

[3] Awal, M.A. (2014). "Correlation between the chemical composition of the surface sediment and water in the mangrove forest of the Sundarbans, Bangladesh, and the regeneration, growth and dieback of the forest trees and people health"..Journal of Science Innovation; 2014. 2(2): pp.11-21.Science Publishing Group, USA; May 20th, 2014(2):11-21;doi: 10.11648/j/si.20140202.11.

[4] ADB, 1992. Non-Wood forests Products. Project 372001/9; forest master Plan, Bangladesh. Asian development Bank, Manila, Philippines: 46-50.

[5] Asian Development Bank, 1993-95. Main Plan-1993/2012. Vol.1. Forestry Master Plan. Asian Development Bank, Manila, Philippines.

[6] Ahmed, K.J. 1957. Tidal forests of East Pakistan, their growth and regeneration. The Pakistan Journal of Forestry, Volume, Deradun, Pakistan.

[7] Bakshi, B. K. 1954. Wilt disease of Dalbergia sissoo Roxb due to Fusarium solani Sensu Snyder and Hensen. Natural Nature 174: 278-291.

[8] Balmforth, E. B. 1985. Observation on Sundri top dyingdescriptive Sampling. In the Sundarbans reserved forest. Draft Working Paper, UNDP/FAO Project BGD/77/017, and Dhaka.32 pp.

[9] Banik, H. 2000. Bangladesh Sundarbans. Hitutumi Book House and Publishers.TalpukurPar, Comilla, (in Bangla), Bangladesh.

[10] Blasco, F. (1977). Outlines of Ecology, Botany and Forestry of the Mangals of the Indian sub-continent. In: Wet coastal ecosystem (ed. V.J. Chapman), Elsevier, Amsterdam 13(1), 19(2).

[11] Chaffey, D. R; Miller, F.R; Sandom, J. H. 1985. A forest inventory of the Sundarbans, Bangladesh, Main report, Project Report No.140, 196 pp; Overseas Development Administration, London, U.K:195-196.

[12] Chaudhury, A.M. 1968. Working Plan of Sundarbans Forest Division for the period from 1960-61 to 1979-80, 82: East Pakistan Government Press, Dacca.

[13] Chowdhury, J. H. 1973. Preliminary report of the investigation of the top dying of Sundri in the Sundarbans. BFRI, Chittagong, Bangladesh, 2 p.

[14] Chowdhury, J. H. and Baksha, M.W. 1983. Studies on the role of Chrysocroa sp. in the initiation of top dying of Sundry. Bano-Biggyan Patrika, 12 (1\&2): 30-34.

[15] Chowdhury, A.M. 1984. Integrated Development of the Sundarbans, Bangladesh: Silvicultural Aspects of the Sundarbans. FAO Report No / TCP/ BGD/ 2309 (Mf), W / R003. 
[16] Chowdhury, M. I. 1984. Morphological, hydrological and ecological aspects of the Sundarbans. FAO report N0. FO: TCP/BGD/2309(Mf) W/R0027, 32 P.

[17] Curtis, S.J. 1933. Working Plan for the forests of the Sundarbans Division, for the period from $1^{\text {st }}$ April 1931 to $31^{\text {st }}$ March, 1951, Vol.1, 175 p. Bengal government press, Calcutta, India.

[18] Ellison, J. C. 1998. Impacts of sediment burial on mangroves. Marine Pollution Bulletin 37: 420-426.

[19] Ellison, J. C. 2000. Mangrove restoration: Do we know enough? Restoration Ecology. 8: 219-229.

[20] Faizuddin, M. 2003. Research on the Top Dying of Sundri in Bangladesh: 43, Mangrove Silviculture Division, Bangladesh Forest Research Institute, Khulna, Bangladesh.

[21] Faizuddin, M. and Islam, S.A. 2003. Generated Technology and Usable Information of the Mangrove Silviculture. Mangrove Silviculture Division, Bangladesh Forest Research Institute, Khulna, p. 17.

[22] FAO, 1994. Review of the state of world marine fisheries resources. FAO Fisheries resources. FAO Fisheries Technical Approach Paper 335:143.

[23] Forestal, 1960. Forest inventory 1958-59, Sundarban Forests. Forestal International Incorporated, Oregon, Canada.

[24] Fujimoto, K; Miyagi, T; Kikuchi, T; and kawana, T. (1996). Mangrove habitat formation and response to Holocene sealevel changes on kosrae Island, Micronesia. Mangrove and salt marshes, 1:47-57.

[25] Gibson, I.A.S. 1975. Reports on a visit to the People's Republic of Bangladesh, 28 February to 1 April 1975.Unpublished Report, ODA, London, 28pp.

[26] Government of India, 1990. Conservation of Mangroves in India, Ministry of Environment and Forests, New Delhi, August, 1990.

[27] Gupta, D.P. (1982). The control of Resources. Cambridge, M.A: Harvard University Press.

[28] Hassan, M. M. 1984. Soil formation in the recent deltaic region of Bangladesh. Bangladesh Journal of Soil Science 20:37-45.

[29] Hassan, M. M. 1988. Soil and Salinity of the Sundarbans in relation to top dying, regeneration and survival of Sundri. UPR of Bangladesh Forest Research Institute, Chittagong: 9.

[30] Hassan, M. M.; Mazumder, A. H.; Islam, A. T. M. N. and Hossain, A.T. M. E. 1990. Soil, hydrology and salinity of Sundarbans in relation to top dying, regeneration and survival of Sundri (Heritiera fomes) trees. In: Rahaman, M. A.; Khandakar, K.; Ahmed, F.U. and Ali, M.O. (Eds.). Proceedings of the Seminar on Top Dying of Sundri (Heritiera fomes) Trees. Bangladesh Agricultural Research Council, Dhaka: 1- 11.

[31] Hoffman J. A. Katz, J. And Bertness, M. D 1986. Mangrove ecosystem. Journal of Ecology, 72 (2): 621-625.

[32] Howlader, A. S. 1973. Report on the Preliminary investigation of Probable causes of Top-Dying, Regeneration and Survival of Sundri. Unpublished Report, BFRI, Chittagong, 9 pp.
[33] Islam, A. K. M. N. 1982. Physico-chemical properties of Sundarbans mangrove forest. Proceedings of the Second Bangladesh national Conference on Forestry 50-54 p. Dhaka, Bangladesh.

[34] Islam, M. A. 1992. Some relevant information about the Sundarbans Forest Division, Khulna, Bangladesh.

[35] Jimenez, C. Y. 1993. Soil compaction as a constraint to tree growth in tropical and subtropical urban habitats. Environmental Conservation. 20: 35-49.

[36] Jones, G; Battershill, C; and Cole, R. (1992). Marine reserves: do they work? In: C. Battershill (ed.) Proceedings of the International Temperate Reef Symposium, Aucland, New Zealand, p.29-45.

[37] Khan, J. A. 1997. Estimation of unregulated densities by line transects method in Gir forest, India. Tropical Ecology. 38(1): 65-72.

[38] Macnae, W. 1968. A general account of the fauna and flora of mangrove swamps and forests in the Indo-West Pacific region. Advance Marine Biology, 6: 73-270.

[39] Naskar, K. and Mandal, R. 1999. Ecology and Biodiversity of Indian Mangroves, Publishing House, New Delhi, India, Volume, I \& II, p.21.

[40] Paul, S.P; and Hossain, A. T. M. E. 1997. Final report on the SDC-VFFP and SSD-BFRI collaborative studies on soil fertility status under cropland agroforestry systems. SDCVFFP, Dhaka, Bangladesh.

[41] Peters, R.L; and Darling, J. D. (1985). The greenhouse effect and nature reserves. Biological Science, 35 (11): 707- 717.

[42] Phillips, O. L; Gentry, A.H: 1994. Increasing turnover through time in tropical forests. Science, 263: 954-958.

[43] Plice, M.J. 1949. Some effects of salt water on soil fertility. Proceedings of the Soil Science Society of America, 24: 275-279.

[44] Rahman, M.A.; Khisa, S.K. and Basak, A.C. 1983. Top dying of Sundri in Sundarbans, Bono Biggyan Patrica 12 (1\& 2): 69-71.

[45] Rahman, M. A. 1986. Present understanding of top dying of Sundri in the Sundarbans. Paper presented at the $5^{\text {th }}$ Biennial Botanical Conference held at the Department of Botany, Dhaka University: 3.

[46] Rahman, M. A. 1995. Mangrove plant pathology of the Sundarbans reserved forest in Bangladesh, field document No.3 of FAO/UNDP Project BGD/84/056-Integrated Resources Development of the Sundarbans Reserved Forest, Khulna, Bangladesh, p.83.

[47] Rahman, M.A. 2001. Diseases and disorders of tree species in the Sundarbans and their management. In: Siddiqi, N.A. and Baksa, M.W.(eds.). Mangrove research and Development, Bangladesh Forest Research institute, Chittagong: 1986-1997, 3(1 and 2):86-93.

[48] Rahman, M.A. 2003. Genetic Approach to mitigate the top Dying Problem of Heritiera fomes in the Mangrove Forests, Khulna University, Bangladesh, 87pp.

[49] Rahman, M.A. 2003. Mid-term Report on Top Dying of Sundri (Heritiera fomes) and Its Management in the Sundarbans Biodiversity Conservation Project, Khulna.109pp. 
[50] Ross and Shell, 1987. Na and $K$ level in Sundri tissue, Cambridge University press, London. Seidensticker, J. Hai; A. 1983. The Sundarbans wildlife managemen

[51] plan: conservation in the Bangladesh (cited in Chaffey et al., 1985), Bangladesh.

[52] Seidensticker, J. 1986. Large Carnivores and the consequences of habitat insularization, Ecology and conservation of tigers in Indonesia and Bangladesh. In: Cats of the World: Biology, Conservation \& management. (Eds. S. D. Miller \& D.D. Eveutt). Wetidal Wildlife Federation, Washington DC, p. 1-41.

[53] Seidensticker, J. \& Hai, M.A. 1983. The Sundarbans Wildlife Management. Bangladesh coastal zone. International Union for Conservation of Nature. Gland, Switzerland.

[54] Seidensticker, J.; Christie, S. \& Jackson, P.1999. Introducing the tiger. Cambridge University press, London, p.1-3.

[55] Shahidullah, M.1980. Salinity penetration on the south-west of Bangladesh: Impact of reduced low flow of the major rivers of Bangladesh (Seminar).Mimeographed report.10 pp

[56] Siddiqi, N. A; Islam, M. R; Khan, M.A.S. and Shahidullah, M. (1993). Mangrove nurseries in Bangladesh. Mangrove ecosystems occasio-nal papers. International Society for Mangrove Ecosystems, Japan: 1-14.

[57] Singh, V.P; Garge, A; Mail, L.P; and Pathak, S.M. (1986). Some ecological aspects of mangrove forest of Andaman Islands. Journal of Bombay Natural History Society. 83:525-537.

[58] Smith et al., 2000.Heavy Metals in Nigerian crude Oils. AJEAM-RAGEE, Volume 9 October 2004: 78-87.

[59] Snedakar, S .C. 1984. General Ecology: Resource Utilization Potential for the Bangladesh, Dhaka, Bangladesh: 31.
[60] Snedaker, S.C. 1977. General Ecology and Resource Utilization Potential of the Sundarbans, FAO Report No.Fo:TCP/BGD/2309 (MF) W/R, 28 prepared for the Government of Bangladesh, Dhaka: 31.

[61] Sobhan, A.1973. Report on the preliminary investigation of potable causes of top dying of Sundri trees in the Sundarbans. Unpublished report, Soil Science Division, Bangladesh Forest Research Institute, Chittagong.7 pp.

[62] Tamang, K. M. 1993. Wildlife Management Plan for the Sundarbans Reserved Forest. Integrated Resource Development of the Sundarbans Reserve Forest. UNDP /FAO, BGD/84/056, Khulna, Bangladesh.

[63] Thom, B.G.1982. Mangrove ecology- a geo-morphological perspective. 1982, p.3-17.

[64] Tiner, R. W; J R. (1984). Wetlands of the United States: Current Status and Recent Trends. Newton Corner, Massachusetts: U.S. Fish and Wildlife Service, Habitat Resources.

[65] Troup, R.S. 1921. The Silviculture of Indian TreesVolume 1. Clarendon Press, Oxford: 153-544.

[66] UN-ESCAP, 1987. Final Report: Volume 2. Coastal environment management plan for Bangladesh. Bangkok, Thailand.

[67] UN-ESCAP, 1988. Coastal environment management plan for Bangladesh. Bangkok, Thailand: 7-34.

[68] UNESCO, 1997. Convention Concerning the Protection of the World Cultural and Natural Heritage, France, Paris.

[69] WHO, 1981. Resistance of Disease vectors to pesticides. World Health. 